This is the version of the article accepted for publication in Public Management Review published by Taylor \& Francis: https://www.tandfonline.com/loi/rpxm20

Accepted version downloaded from SOAS Research Online: http://eprints.soas.ac.uk/30172

Public Services Reforms in Neo-Patrimonial Systems:

The Commercialization of Healthcare and Education in Saudi Arabia

\author{
Dr Alberto Asquer \\ Lecturer of Public Policy and Management \\ School of Finance and Management \\ SOAS University of London \\ London, UK \\ Email: aa144@soas.ac.uk \\ Phone: +44(0) 2078984757 \\ and \\ Dr Ahmed Alzahrani \\ Director of the IPA Business Center \\ Institute of Public Administration \\ Department of Economics and Finance Programs \\ Riyadh, Saudi Arabia \\ Email: zahraniaa@ipa.edu.sa
}




\title{
Public Services Reforms in Neo-Patrimonial Systems: \\ The Commercialization of Healthcare and Education in Saudi Arabia
}

\begin{abstract}
Reforms of public services have been extensively researched in representative democracies, where they have been especially explained by ideological change, political turnover, financial crises and pressures from international organizations. Meanwhile, less attention has been paid to explaining them in countries whose institutions have been characterized as neo-patrimonial systems. This study aims to explain the commercialization of healthcare and education services that took place in Saudi Arabia since the 2000s. The analysis provides some ways to refine and expand existing theoretical accounts of public services reforms in regimes that differ from representative democracies.
\end{abstract}

Keywords: Public services reform; neo-patrimonial systems; commercialization of public services; Saudi Arabia. 


\section{Public Services Reforms in Neo-Patrimonial Systems: \\ The Commercialization of Healthcare and Education in Saudi Arabia}

\section{INTRODUCTION}

Reforms of the provision of public services have been documented by several studies that explained various forms of privatization, contracting out, outsourcing, and 'marketization' of systems of public service delivery (Wise 1990; Miranda and Lerner 1995; van Slyke 2003; Brewer and Walker 2010). These studies were especially attentive to the role that contemporary democratic and capitalist institutions play in shaping and promoting the adoption of neoliberal policies and programs (Steger and Roy 2010; Dahl and Soss 2014). Public services reforms have been related, for example, to political turnover and shifts of political economy ideology away from the 'publicness' of public services (Haque 2001; Hood 1991, 1995a, 1995b; Weyland 2002). Their diffusion has been associated, inter alia, with the fiscal crisis of the state and the pressures from the international organizations of the 'Washington Consensus', namely the World Bank and the IMF (Mascarenhas 1993).

The propagation of public services reforms across the world has taken place also in countries where institutions deviate from democratic and capitalist ones (Beeson 2001; Moloney 2007; Gulrajani and Moloney 2012). The introduction of reforms in countries like China, Russia, and Saudi Arabia, in particular, defies the standard account of public services reforms because of the presence of local political and economic institutions that curb political turnover and ideological shifts, and of context conditions that help contain fiscal stress and international pressures. Closer attention is needed to the political economy of public services reforms in order to explain why such reforms take place in countries that do not possess the kind of democratic and capitalist institutions that are typical of representative democracies as Western countries do (Welch and Wong 1998). 
The political economy regime of countries like China, Russia, and Saudi Arabia has been characterized as a neo-patrimonial one. The term neo-patrimonialism is used to indicate systems where formal, legal, and rational forms of domination and legitimacy coexist alongside informal, charismatic, and patrimonial ones (Riggs 1964; Chapman 1966; Eisenstadt 1973). In neopatrimonial systems, policy change takes place within a context of political and economic institutions that may bear some formal resemblance to representative democracies, but which operate in a fundamentally different way (Helmke and Levitsky 2004). Neo-patrimonial systems, for example, may not tolerate political turnover and ideological shifts (Lindberg 2003). In addition, when neo-patrimonial regimes build on systems where the government enjoys control of large sectors of the economy (like for example the oil and gas industries in rentier states), they are more reluctant to capitulate to fiscal stress and international pressures (Ross 1999).

If neo-patrimonial systems do not experience conditions that are typically associated with representative democracies, how can we explain why such countries undertake public services reforms? An answer to such question has theoretical relevance because it would help reconsider conventional explanatory arguments for public services reforms under conditions that diverge from those ordinarily associated with public services reforms in representative democracies. This study aims to address this question through the case study of the commercialization of healthcare and education in the Kingdom of Saudi Arabia, a country that is considered to exhibit the quintessential traits of neo-patrimonialism. Since the 2000s, the Saudi government promoted the establishment of 'business centers' for the delivery of healthcare and education services through commercial practices alongside the installed systems of public service delivery. Yet, the commercialization of healthcare and education was not related to any political turnover or ideological shift, or to any deliberate consideration for the sustainability of the Saudi rentier state in the future. Explaining the commercialization of healthcare and education in Saudi Arabia would result in tentative analytic generalizations (Yin 2003) about the commercialization of public services that are inclusive of 
conditions that occur in neo-patrimonial systems and not just in representative democracies. In such a way, this study contributes to carry forward a research program that aims to enrich theoretical accounts of public services reforms by looking at reform experiences in non-Western countries.

The rest of the paper is organized as follows. First, we will review the literature on public services reforms and on the definition of neo-patrimonial systems. Next section will illustrate data collection and analytical method. The following sections will narrate the episode of the commercialization of education and healthcare in Saudi Arabia since the 2000s and will provide an explanatory argument. Finally, the last section will draw the conclusions of the study.

\section{EXPLAINING PUBLIC SERVICES REFORMS}

During the last decades, many representative democracies reconfigured the systems of public services delivery in ways that were largely consistent with neoliberal policies. Neoliberal policies typically originate from a normative preference for minimal state intervention in the society and reliance on the market system for coordinating the production and allocation of goods and services in the economy (Beeson and Firth 1998; Harvey 2007a). Public services reforms of neoliberal sort take different forms, including privatization, contracting out, outsourcing, and the 'marketization' of systems of public services delivery (Christensen and Laegreid 2001; Greve 2006; Powell et al. 2010). The term 'commercialization' has been also used to refer to the introduction of exchange transactions in the provision of public services like healthcare and education (Spicer et al. 1996; Pollitt and Talbot 2003; Laegreid et al. 2011).

Several studies have documented the rationales, effects, and modalities of the commercialization of public services (Dixon et al. 1996; Lucio et al. 1997; Joyce 1999; Brown et al. 2000; Evers 2005; Wollmann and Marcou 2010). Reforms of the provision of public services typically happen for reasons of finance, efficiency, and service quality. Financial reasons include the attainment of 
financial self-sufficiency for public sector service providers in the context of increasing costs (especially arising from growing expectations from the public and escalating investments to keep pace with technological advancements) and mounting pressure on public revenue and fiscal balances (Creese 1991; Mossialos et al. 2002; Evans and Etienne 2010). Efficiency reasons take, for example, the form of arguments about the role of prices to contain consumption of public services and to make managers pay more attention to full cost recovery (O'Faircheallaigh et al. 1999). The commercialization of public services, moreover, is expected to stimulate service quality because of greater responsiveness to the demands of users, who benefit from increased choice options between alternative public service providers (Jordan 2006).

The commercialization of public services entails various repercussions on both users and service providers. Sometimes, commercializing public services may be unpopular with the public and ineffective to promote cost-efficiency and quality. For example, the commercialization of higher education often results in increased financial burden on the students and their families (Barr 1993; Dixon and Kouzmin 1994; Marginson and Considine 2000; Greenaway and Haynes 2003). In healthcare services, commercialization may give rise to barriers to access and, relatedly, to the marginalization of the weaker parts of the society (Hercot et al. 2011; Lagarde and Palmer, 2011; Prinja et al. 2012). The introduction of commercial practices into systems of public services provision may also trigger conflicts between different 'institutional logics' (Reay and Hinings 2009; Goodrick and Reay 2011) held by public service professionals (like teachers and physicians) and by public managers. Issues arise, consequently, around the redefinition of identities and roles of individuals who can either defend their occupational spaces from commercialism or acquire 'hybrid' characters that combine business-oriented and public service-oriented traits (Fitzgerald and Ferlie 2000; Montgometry 2001; McGivern et al. 2015). 
Explanatory accounts of public services reforms have often remarked on the analytical importance of context conditions (Pollitt 2013). Conditions that have been related to public services reforms in representative democracies include the coming to power of political parties and leading figures that lean favorably towards the commercialization of public services and the championing of free market ideologies reflecting influential academic and think tank circles (such as the Chicago school of economics) (Peters and Savoie 1994). Both these conditions are closely related to features of the context of democratic and capitalist institutions in Western countries, where the political regime permits the turnover of parties in power and the economic system provides for entrepreneurial efforts to exploit emergent market opportunities.

The diffusion of public services reforms has also been explained on the basis of additional conditions that include, inter alia, the fiscal crisis of the state and the pressures from international organizations of the 'Washington Consensus' (Harvey 2007b). Conditions of stress on public finances help account, for example, for the recourse to privatization and forms of commercialization that are pursued to raise public revenue and shrink the size of the public sector in countries that are severely hit by financial crises, such as, for example, Asian countries after 1997 and some European countries like Cyprus and Greece in the aftermath of the sovereign debt crisis since 2009. Pressures from international organizations help explain, for example, the adoption of neoliberal reforms in the health sector in Latin American countries (Homedes and Ugalde 2005) and in the education sector in developing countries of Asia and Africa (Ball and Youdell 2008).

Finally, the diffusion of public services reforms has also been explained with reference to transmission mechanisms across countries. This argument builds on the general tenets of policy transfer where countries that act as 'followers' import policy reform ideas from other countries that behave as 'leaders' or 'early movers' (Dolowitz and Marsh 1996, 2000; Stone 2004). At a superficial level, such pattern could be discerned in the diffusion of public services reforms - especially based 
on the New Public Management (NPM) doctrine - from Westminster countries to other parts of the world since the 1980s. Transmission mechanisms that could help the transfer of NPM policies across countries include, for example, the role of knowledge brokers (Barzelay and Gallego 2010) and of the construction of the issue image of public services reforms as one of modernization of traditional public bureaucracies (Hood 2000; Hood and Dixon 2015). The role of policy transfer, however, has been questioned because of the importance of idiosyncratic conditions related to country history and politics (Goldfinch and Wallis 2010; Hood 1995a, 1995b).

\section{PUBLIC SERVICES REFORMS IN NEO-PATRIMONIAL SYSTEMS}

During the last decades, reforms of public services have been made in countries whose political and institutional systems deviate from representative democracies, like China, Russia, and Saudi Arabia. In the late 1970s, China undertook various reforms that gradually introduced market institutions and practices - albeit in a centrally coordinated fashion - into the economy together with the privatization of state-owned enterprises and the restructuring of the welfare and healthcare systems (Leung 1990; Kuo 1994; Bloom and Xingyuan 1997; Wong 2009; Bloom 2011). In Russia, following a period when the country moved away from a centrally planned economy to a market system (a process that was accompanied by controversial privatizations) in the 1990s, the government undertook reforms of the public sector (Barabashev and Straussman 2007) that included, in particular, the introduction of commercial services into public healthcare facilities and granted a larger role for private providers (Rechel and McKee 2009; Gordeev et al. 2011). In Saudi Arabia, during the reign of King Abdullah (2005-2015) various piecemeal reforms were passed which introduced some amount of privatization, deregulation, and openness to foreign investments, together with measures that were intended to increase transparency and accountability in the public sector. In the reign of King Salman (2015-), then, the government adopted a wholesale approach to reform the public sector with the formulation of a strategic plan (called Vision 2030) that included objectives like '[to] increase private sector share of spending through alternative financing methods 
and service provision' in healthcare and '[to] increase private sector participation' in the education sector.

Features of the political and institutional regime of countries like China, Russia, and Saudi Arabia have been characterized as neo-patrimonial ones. Neo-patrimonialism is a convenient construct that refers to political and institutional systems that blend traditional forms of authority and legitimacy (patrimonial systems) with modern ones (Riggs 1964; Chapman 1966; Eisenstadt 1973). Neopatrimonialism arises in the context of modernization, where systems of power that are historically based on charismatic and paternalistic forms of domination are adjusted to socio-cultural norms that center on principles of rationality and legality (Weber 1968). The combination of traditional and modern forms of domination results in systems where informal institutions exist alongside formal ones (Bratton and van de Walle 1997; Erdmann and Engel 2007).

Neo-patrimonial systems carry various implications for political and societal relationships. The public and the private spheres are formally separated but, in practice, their boundaries are blurred and provide more opportunities for private appropriation of public resources than in more formal and bureaucratic systems (Marquette and Peiffer 2017). The political elites maintain clientelistic ties with social groups that tend to provide support in exchange for particularistic benefits rather than universal public services. In addition, the power structure is strongly based on personal relationships between the ruler and the ruled (Weber 1948; Bendix 1996), with the effect that decisions can be made on an ad hoc basis rather than in a transparent and unbiased way. These features affect the policy process in ways that diverge from political and institutional systems like representative democracies (although selected features of neo-patrimonial systems may partially characterize Western countries also) and their variants, for example the administrative reforms in the Japanese deliberative society (Wright and Sakurai 1987) and in Eastern European new democracies (Neshkova and Kostadinova 2012). 
Prima facie, neo-patrimonial systems do not seem favorable to reforms of public services. In neopatrimonial systems, power elites may be reluctant to open up the provision of public services to commercialization because access to services through market transactions would erode their selective control of benefits to the clienteles. Political institutions may prevent dramatic shifts in the policy orientation of governments because of lack of elections or ostracism towards ideologies that are not compatible with the dominant value paradigms. Especially if a neo-patrimonial system builds on the economic conditions of a rentier state (where a large share of public revenues originate from domestic natural resources), power elites may not feel threatened by financial crises or by pressures from international organizations. Alternative explanations are needed, therefore, for the reforms of public services that take place in countries with a neo-patrimonial political and institutional context.

\section{RESEARCH METHOD}

The issue of why public services reforms take place in neo-patrimonial systems is tackled here through the case study of the commercialization of healthcare and education services in Saudi Arabia. The case is selected as an exemplar of the issue scenario under consideration, which plays the role of 'counterfactual' (Lebow 2000; Fauconnier and Turner 2008) in an explanatory argument about public services reforms with respect to alternative scenarios where reforms of the provision of public services take place within political and institutional systems of representative democracy. As such, the case of Saudi Arabia can be understood as a 'critical' one (Flyvbjerg 2006) with respect to the ordinary conditions of the commercialization of public services in representative democracies. A critical case study challenges and extends existing theories by adjusting generalizations in such a way as to account also for the conditions of the critical case itself (Elman et al. 2016). 
The case study consists, more precisely, of the introduction of commercial practices within 'business centers' attached to public sector providers of healthcare and education services. Partially departing from a regime of full government funding and free-of-charge service delivery, from the mid-2000s Saudi healthcare and education service providers started diversifying their undertakings into for-profit activities, such as, for example, training civil servants and professionals and delivering healthcare services within the same public sector organizations but outside the stipulated working hours. While several business centers were established in the country (Table 1 provides the list of the main ones), evidence will especially focus on the commercialization that took place at the Institute of Public Administration and at the King Fahd Medical City in Riyadh.

[Table 1 here]

Data collection was carried out by one of the authors in the form of twelve interviews (in Arabic) with key informants. Part of the interviewees were selected because of their pivotal role in the healthcare and education service providers, and included the executive director, a member of the board, two members of staff and two institutional clients of the Business Center of the Institute of Public Administration, and two members of staff, a consultant and one institutional client of the Business Center of the King Fahd Medical City. Two interviews were also conducted with members of the Expert Commission (a think tank unit attached to the Council of Ministers), who provided historical accounts of the origin and regulation of public services commercialization in the country. Following a saturation criterion, no further interviews were made when interviewees started providing no additional evidence on the episode of interest. Evidence from the transcribed interviews was partially triangulated with secondary sources, in the forms of government documents, business centers' documents, media and policy reports. As it was noticed in the past, the Arab policy context is one where researchers experience difficulties to gather records of decisions, 
whose rationales may often originate just from personal preferences of senior leaders (Tayeb 2004) and may have not left written traces behind.

Evidence from the case study was used in a grounded theory development approach (Tummers and Karsten 2012) in order to construct an understanding of the cognitive structures of the social domain under consideration. The analysis of data was attentive to identifying features of the context that could relate to the commercialization of healthcare and education services. The causal relationships between context features and the commercialization of healthcare and education services were articulated with the introduction of social mechanisms (Hedström 2005; Hedström and Swedberg 1998; McAdam et al. 2001) - which are conceived as interpretations (Schelling 1998) or hypothetical causal models (Gambetta 1998) of social phenomena. Social mechanisms are often used in public policy and management research because of their contribution to theorize causal inferences about social processes (Barzelay and Gallego 2006; Bates et al. 1998; George and Bennett 2005). The result of the analysis takes the form of plausible hypotheses about the social process under consideration (Hedström and Swedberg 1998). Following this approach, the Saudi Arabia case provides some evidence to support the formulation of new or revised causal conditions for the reform of public services that specifically apply to the context of neo-patrimonial systems.

\section{CHANGING FEATURES OF THE SAUDI PUBLIC SECTOR}

During the last decade, the provision of public services in Saudi Arabia started to exhibit stronger customer orientation, adoption of business initiatives, and opportunities for users' choices. In the healthcare and education sectors, in particular, the establishment of 'business centers' resulted in the adoption of commercially-oriented practices for the delivery of training programs and healthcare services. Although the country had already followed a trajectory of relative 'modernization' since the 1970s, the introduction of such reforms - broadly related to the idea of 
marketization of public services - disrupted a long-established tradition of centralization and bureaucratic administration of the healthcare and education sectors.

The Saudi administrative tradition of centralization and bureaucracy can be traced back to the very origins of the country. The unification of the kingdoms of Hejaz and Najd into the Kingdom of Saudi Arabia under Abdulaziz Al Saud in 1932 resulted in the formation of a state administration that centered on the role of the King (and, relatedly, of the royal family), who exerts supreme authority in the interpretation and execution of Sharia (the Islamic law) and control of the bureaucracy at the level of the central government and of the 13 provinces of the country (Jabbra and Jabbra 2005; Al-Otaibi 2010). Since the unification, the King and the royal family have exerted a strong influence on Saudi public administration, whose practices have been also affected by the application of principles of wasta, which broadly consists of a system of patronage built on the basis of family and tribal ties (Al-Awaji 1971; Jabbra and Jabbra 2005; Idris 2007; Common 2008).

The historical and cultural conditions at the origin of the Saudi public administration resulted in the consolidation of paternalistic, hierarchical and authoritarian management practices (Tayeb 2004). The organizational culture of the Saudi public administration, which is strongly rooted in religion, tradition, and the community (Common 2008), has long exhibited traits of high power distance and collectivism (Barakat 1993; Bjerke and Al-Meer 1993; Jabbra and Jabbra 2005; Mellahi 2006; Idris 2007). Decision-making style followed high uncertainty avoidance and consultation with in-groups, with the effect that even minute administrative problems have been typically passed up to the attention of senior officers (Jabbra and Jabbra 2005). A conservative attitude towards change, coupled with lots of regulation and red tape, has typically hampered innovation and improvement (Common 2008). 
An account of the changing features of Saudi public services cannot escape, moreover, the role that oil played in the economic and administrative development of the country. After the beginning of the oil exploitation in the 1930s, and especially since the discovery of the largest oil field in the world, Ghawar, in 1948, Saudi Arabia enjoyed a continuous flow of oil revenue which funded more than $80 \%$ of the public sector budget, apart from increasing the riches of the royal family (Kamrava and Mora 1998; Lucas 2004). As a rentier state, Saudi Arabia pursued the development of generous welfare in the forms of free healthcare and education services, subsidized prices for fuel and other commodities, supply of desalinated water, and other forms of public benefits.

While oil revenue provided the opportunity for Saudi Arabia to enjoy instant prosperity, it also brought about profound changes in the society and the economy. Improvements of material conditions were accompanied by dramatic growth of the Saudi population, with consequential effects on demand for more and better public services. Under the kingdom of Faisal (1964-1975), the public sector expanded to include more healthcare and education services, social security, television and telecommunications, and the central government started developing the capacity to plan and execute development projects (Al-Tawail 1995). His successor King Khalid (1975-1982) continued pursuing the strengthening of the public sector, which stimulated further immigration including that of skilled workers and professionals who compensated for the lack of qualified local labor resources (Al-Awaji 1971; Al-Ahmadi and Roland 2005; Jabbra and Jabbra 2005). The emergence of a new class of professionals, partially related to a limited privatization of the economy (Bertucci 2004), stimulated the establishment of quasi-representative bodies like the Consultative Council (Majlis al-Shura), formed of professional, religious and academic advisors, and of Provincial Councils under King Fahd (1982-2005). The pervasive presence of foreigners among the workforce also triggered the adoption of Saudization policies (Gallager 2002), which were also intended to tackle the growing unemployment in the country (although the expected increase in the proportion of Saudi employees was not attained; Mellahi 2006). 


\section{The establishment of business centers}

It is within this historical context that the reform of the provision of public services took place. The early business centers were established within the education sector. In 1997, the King and the president of the Council of the Ministers approved the proposal to establish a business center at King Saud University, which would mark the launch of commercial activities in the largest university of the country. King Saud University was permitted to provide paid consultancy, research, educational and training services to public, private and non-profit organizational alike, which were offered through the newly established King Abdullah Institute. In various respects concerning the design and delivery of the services, the management of the King Abdullah Institute drew lessons from a comparative analysis of the commercial undertakings of major US and UK universities.

The commercialization of the health sector followed in 2001, when the Council of the Ministers mandated that public healthcare organizations establish business centers too. The decision of the Council originated from conditions that were peculiar to the Saudi health sector. Three years earlier, a special committee had been formed within the Council and charged with the task to address the issue of the shortage of skilled professionals and the competitive pressures to public healthcare organizations from the private sector and job opportunities abroad. The committee suggested to allow public healthcare physicians (whom the Saudi law prohibited to work privately even on parttime basis) to work extra hours which would be paid by charging fees to evening patients. The Council envisaged that the commercial healthcare services of the business centers could provide a way to fulfil the salary expectations of physicians and to retain them in the public sector.

In 2003, the Saudi government established the General Memorandum Committee Administrative Reform, which was charged with supervising the restructuring of the public sector (Al-Otaibi 2006). 
Most of the reform efforts of the Committee focused on fixing duplications and overlaps between a plethora of government agencies, but it also called for providing better services in the healthcare and education sectors. More universities and public healthcare companies followed the early steps of King Saud University by diversifying their activities into commercial branches, which would provide paid ancillary services while the parent entities would carry out their statutory services for free. Several business centers were established during the 2000s.

In part, the introduction of commercial practices in the healthcare and education sectors was intended to fulfill demand for additional training programs and better healthcare services. In part, the establishment of the business centers also offered opportunities to earn additional income for academics and physicians who performed services beyond the stipulated working hours. Extra income sources were specifically intended to help public sector entities attract and retain highly skilled professionals, whose salaries at the Saudi universities and public healthcare providers were below market rates. The health sector, in particular, was extremely dependent on foreign physicians (who catered for about $80 \%$ of the service; Al-Sheri 2010) who could be attracted by better economic conditions in neighboring countries. In addition, the establishment of business centers was also welcome at the government level because it was expected to stimulate the development of the private sector, to trigger improvements of service quality and cost-effectiveness, and to encourage innovation.

\section{The commercialization of healthcare: The Business Center of the King Fahad Medical City}

Established in 2005, King Fahad Medical City (KFMC) was intended to be one of the largest independent medical complexes in the Middle East, with a total capacity of about 1,200 beds. Fully funded by the Saudi government, KFMC comprised four hospitals that could treat more than 50,000 in-house patients and over two million out-patients per year. Since its creation, KFMC was allowed to carry out commercial activities, which were undertaken by a business center (KFMC BC) that 
generated income for the Resource Development Fund (RDF) of KFMC, established in 2007 by the Council of Ministers. Headed by a board that included executive members of KFMC and two representatives from the Ministry of Finance and the Ministry of Health, the RDF was granted legal and financial autonomy to manage and develop the asset base and businesses of KFMC.

The commercial activities of the KFMC BC were arranged in close coordination with the healthcare services of the KFMC. In contrast to the patients of the KFMC, who were treated for free, those of KFMC BC paid a fee but were hospitalized under the same procedures and shared the same facilities of KFMC patients. Patients that were serviced through KFMC BC could benefit from shorter waiting lists, but both classes of patients received services of commensurate quality. Physicians did not differentiate between KFMC and KFMC BC patients. Income generated from the commercial activity of KFMC BC largely accrued to the RDF, which invested into medical facilities of KFMC although it also shared part of the profit with KFMC departments.

\section{The commercialization of education: The Business Center of the Institute of Public}

\section{Administration}

The Institute of Public Administration (IPA) was established in 1961 as an autonomous government agency charged with the statutory aim to improve the quality of the country's public administration and economic development. IPA was required to provide education to public employees in order to improve efficiency and effectiveness in the implementation of government policies and programs and to increase their accountability to the public. In addition, IPA provided various consulting services to government entities, including organizing administrative systems, advising on administrative issues, carrying out research work, and promoting principles of efficiency and effectiveness in public administration. 
In 2006, IPA established its Business Centre (IPA BC) with the aim to fulfil growing demand for training and advisory services and to expand IPA's offerings into market areas that were not included in the original IPA statutory mandate, such as services for the private sector and for semigovernmental entities. The vision of IPA BC was to 'be pioneering and outstanding in offering high-quality services in the various fields of administrative development, which can serve as an example to be followed on the local, regional, and global levels'. The mission of IPA BC was 'to provide both the public and the private sectors with high-quality training, consultative, and research services in a unique way that meets their expectations and guarantee their satisfaction'. Business areas of IPA BC included the provision of training services, consulting, advice and research, the organization of seminars, symposia, and exhibitions, and other forms of utilization of IPA BC's facilities at the IPA premises. Provision of training services rapidly became a main business area of IPA BC, in the form of general-purpose and special-purpose training programs, general and special qualification preparatory programs, and seminars for administrative leaders.

As the commercial activity developed, it became apparent that IPA BC lacked full autonomy from the parent entity. The requirement that IPA employees perform commercial activities outside the stipulated working hours, for example, limited the delivery of training programs to evenings and weekends only. IPA BC had little scope to set its own strategic direction and resource allocation policy. As a result, IPA BC hardly expanded its commercial activity beyond the public sector and its engagement with business entities remained relatively circumscribed. Lately, IPA BC has undertaken more aggressive marketing efforts, especially by establishing a Marketing department and hiring dedicated staff to develop its commercial activity in a corporate style. IPA BC has established a strong network of partnerships with many global private consulting firms to improve its offering and to cover a wider range of services provided to other government agencies and private sector firms. These efforts resulted in a 20-fold increase in revenue in 2017. 


\section{EXPLAINING PUBLIC SERVICES REFORMS IN SAUDI ARABIA}

The study of public services reforms in neo-patrimonial systems adds further variety to the repertoire of country cases that reformed their system of public service delivery and which have been investigated in comparative perspective (Barzelay and Gallego 2010; McLaughlin et al. 2002; Pollitt and Bouckaert 2004). Neo-patrimonial systems provide a different context against which existing theoretical arguments can be tested. In particular, evidence of public services reforms in neo-patrimonial systems calls for explanations that challenge the assumptions that are typically held for public service reforms in representative democracies. Evidence of public services reforms in neo-patrimonial systems, therefore, can suggest new or refined propositions with respect to those that are already part of existing theoretical accounts.

Existing approaches to explaining reforms of public services tend to focus on the role of ideological change, political turnover, financial crisis and pressures from international organizations. Yet, the case of the commercialization of healthcare and education services in Saudi Arabia suggests that these factors play a limited role in the context of the Saudi neo-patrimonial system. First, the Saudi political and societal conditions are not conducive to any shift of dominant political economy ideology. The country's political and institutional regime rules out any turnover of political leaders outside the stipulated royal descendent line. The introduction of commercial practices in Saudi healthcare and education services, therefore, cannot be related to any reform initiative that originates from electoral and party politics dynamics.

Reliance on oil revenue, moreover, made the Saudi state relatively immune from the prospect of financial crisis and from the pressure of international organizations. Since the turn of the century and until the Great Financial Crisis, the Saudi government enjoyed the fiscal effects of a dramatic increase of oil prices. No short-term pressure, therefore, helps account for the introduction of commercial practices in healthcare and education services in the country. It could be argued that 
such conditions of Saudi Arabia are not immutable, however: political leaders could anticipate the end of oil revenue in the medium-long term and deliberately stimulate the introduction of public services reforms as a way to start preparing the Saudi society to a post-oil regime. The country's development plans from 1996 onwards provided, indeed, that the Saudi economy should diversify away from the oil industry and concede a greater role for the private sector. No planning document, however, stipulated that services like healthcare and education should be commercialized. Although Saudi leaders could possess the farsightedness to set the national economy on a new course, this argument does not suffice to explain the introduction of commercial practices in the healthcare and education business centers, whose origin can be better traced to local circumstances and pragmatic reasons than the execution of a wholesale reform plan.

Additional approaches to explaining public services reforms also highlight the role of transmission mechanisms that result in the adoption of policies that originate from abroad. It would be analytically inadequate to consider the case of the commercialization of healthcare and education services in Saudi Arabia in isolation from the international context. Indeed, the very design and delivery of services in the first business center of the educational sector, the King Abdullah Institute, was partially inspired by the commercial undertakings of major US and UK universities. Yet, no evidence has been collected that transmission mechanisms played a role in the decision to commercialize healthcare and education services in Saudi Arabia. The establishment of business centers seemed to derive from the domestic discourse around the modernization of the Saudi economy and society rather than from any explicit influence of foreign antecedents and policy brokers. The following explanation of the commercialization of healthcare and education services, therefore, mainly builds on the evidence collected on the role of features of domestic conditions of the Saudi public services policy sub-system. 
In order to explain the commercialization of healthcare and education services in Saudi Arabia, we first recall some characteristics of the political and institutional context. As other neo-patrimonial systems, the Saudi one adopts a conservative attitude towards change, which is pursued through consensual arrangements within powers structures that tend to preserve stability of existing power relationships. These features of the Saudi context counteract tendencies that are commonly related to public services reforms. Rather than ideological shifts, novel ideas seem tolerated in the Saudi context when they are incorporated within local narratives of modernization and pragmatic adjustments. Rather than political turnover, the Saudi context favors continuity of leadership along dynastic lines. Rather than being exposed to pressures that originate from financial crisis or international organizations, the Saudi context provides some room for pursuing relatively autonomous domestic fiscal policies.

In explaining how features of the neo-patrimonial system of the Saudi context act as neutralizers of factors that are commonly associated with public services reforms, we consider the role played by a combination of mechanisms of committed interpretation and actor certification. Committed interpretation is a social mechanism that "binds an individual to his or her behavior. The behavior becomes an undeniable and unchangeable aspect of the person's world, and when he makes sense of the environment, behavior is the point on which constructions or interpretations are based" (Salancik and Pfeffer 1978: 231). In the Saudi context, committed interpretation helps account for the inclination of individuals to retain consistency of their beliefs and conduct in the delivery of public services over time. The case evidence shows that ideas about the commercialization of public services were incorporated into the reform of the healthcare and education sectors, where business centers were allowed to undertake commercial activities albeit within the control of the parent organizations. Committed interpretation suggests that such form of commercialization of healthcare and education services could result as a partial translation of neoliberal ideas into the cognitive and social frame of reference of a neo-patrimonial society, where individuals tend to reproduce the 
particular combination of hierarchical and consensual modes of coordination. Committed interpretation also helps to explain that beliefs about the present state of the Saudi economy - where oil revenue account for more than $80 \%$ of public sector budget - could result in the denial of any exposure to imminent financial crisis.

Actor certification provides an additional component to the explanation of the commercialization of healthcare and education in Saudi Arabia. Actor certification refers to the "validation of actors, their performances, and their claims by external authorities" (Tilly et al. 2001: 121). In the context of a neo-patrimonial system, actor certification limits the venues through which policy change may occur because only a restricted circle of individuals who are legitimized by the political and institutional regime can propose and carry out change. Actors who are not certified by the ruling power - like, for example, alternative political coalitions and foreign institutions - would be barred from entering the policy discourse about the reconfiguration of public services provision. The two mechanisms of actor certification and committed interpretation would act in concert (Gambetta 1998), with the effect of limiting the role of external influences on the making and implementation of public services reforms.

In addition to conditions that arise from the Saudi context, we should also consider features of the process dynamics of the commercialization of healthcare and education. Evidence shows that the establishment of business centers took place in the education sector before the healthcare one, and that the decision to commercialize healthcare services took into account the experience of the business centers in universities. A combination of mechanisms of actor certification (Tilly et al. 2001: 121) and availability heuristics (Gigerenzer and Gaissmaier 2011) helps explain how the early adoption of business centers in education could have affected their introduction in healthcare. In part, the previous experience in education conferred legitimacy to business centers as appropriate means for commercializing public services. In part, business centers provided the opportunity to 
address the issue of staff retention by adopting a form of commercial service delivery that was readily available to policy-makers' cognitive domain. The commercialization of public services in Saudi Arabia, therefore, took place also through the cross-sectoral transfer of the policy reform feature of business centers.

The evidence from the case of the commercialization of healthcare and education in Saudi Arabia suggests some tentative explanations of public services reforms in neo-patrimonial systems. A mechanism of attribution of opportunities and threats helps account for the introduction of commercial practices for pragmatic considerations. A crucial mechanism in the mobilization of social action, attribution of opportunities and threats consists of "(a) invention or importation and (b) diffusion of a shared definition concerning alterations in the likely consequences of possible actions (or, or that matter, failures to act) undertaken by some political actor" (McAdam et al. 2001: 95). In the Saudi Arabia case, the commercialization of healthcare and education provided the opportunity to stimulate alternative forms of funding for investment in healthcare services and to generate more attractive salary conditions for education and healthcare professionals. In addition, a sense of threat arising from the prospect of a post-oil economy could facilitate the concession of a limited amount of autonomy to business centers. The commercialization of healthcare and education, therefore, is only partially accounted for by the foresightedness of political leaders, which should be better understood within the context of initiatives that could help preserve the existing systems of public authority and legitimacy. The key components of the explanatory argument presented in this section are summarized in Table 2.

[Table 2 about here]

The explanatory arguments for the commercialization of healthcare and education in Saudi Arabia provide some way to refine and expand existing theoretical accounts of public services reforms. 
With respect to causal conditions that are derived from the literature, evidence from the Saudi Arabia case suggests that factors such as ideology change, political turnover, financial crises and pressures from international organizations (hypothesized causal conditions No. 1-4 in Table 2) are partially neutralized. A tentative explanation for the neutralization of these factors arises from the mediating role of social mechanisms like committed interpretation and actor certification, which can help explain why Saudi policy-making was relatively immune from conditions that past research showed to relate to public services commercialization in representative democracies. The case study suggests, therefore, that ideology change, political turnover, financial crises and pressures from international organizations do not provide necessary conditions for the commercialization of public services to take place.

On the other hand, evidence from the Saudi Arabia case suggests that the commercialization of healthcare and education could have been stimulated by the anticipation of future conditions, namely the prospects of financial pressures on the public sector in the post-oil economy scenario (hypothesized causal condition No. 5 in Table 2). Arguably, such condition would have played a role through the agency of political leaders who could be so far-sighted as to undertake preparatory actions to reform parts of the public sector via the commercialization policy. The role of political leaders in the Saudi Arabia case should not be ruled out (as probably in any reform episode). What seems analytically relevant, however, is the role of the mechanism of attribution of opportunities and threats, which helps provide a rationale for why the commercialization of healthcare and education was undertaken. The mechanism of attribution of opportunities and threats can also help account for the role of another context condition, namely the intent to retain skilled professionals into the healthcare and education sectors (hypothesized causal condition No. 6 in Table 2).

Conditions such as the prospect of a post-oil economy scenario and the intent to retain skilled professionals appear as locally contingent to the Saudi Arabia case. The role of the mechanism of 
attribution of opportunities and threats, instead, could be framed as a tentative analytical generalization of the case study. A general explanatory argument for the commercialization of public services, then, is that local conditions may play a causal role in the commercialization reform when they are framed as sources of threats - which would undermine stability of existing power relationships - or of opportunities - which would help fix possible disruptions to existing service delivery arrangements. In addition, evidence from the Saudi Arabia case suggests that the commercialization policy was transferred domestically from one sector (healthcare) to another (education) for reasons that include the combined effects of mechanisms of actor certification and availability heuristics (hypothesized causal condition No. 7 in Table 2). The case study, therefore, suggests that combinations of such social mechanisms could help explain the origin and the diffusion of public services commercialization. Framed in terms of social mechanisms, moreover, such explanatory arguments are not context-specific, and therefore they would be 'portable' (in the sense of Bengtsson and Hertting 2014) to other similar contexts.

The explanation of the commercialization of healthcare and education in Saudi Arabia provides evidence of a piecemeal approach to reforming systems of public service delivery. Rather than a comprehensive transformation of how public services are conceived, planned, costed, measured, managed and delivered, the Saudi government in the early and mid 2000s opened up limited room for experimentation of business-like practices in the healthcare and education services which were primarily pursued for pragmatic considerations. The Saudi experience, in this respect, deviates from other kinds of public services reforms where overarching principles inform the design and implementation of new management practices. For example, the adoption of general principles of accrual accounting in the public sector typically results in widespread consequences on full cost recovery, pricing, transparency and accountability in the provision of public services (Carlin and Guthrie 2003; Carlin 2005). The commercialization of healthcare and education in Saudi Arabia, instead, was not inspired or consistent with any overarching central government policy. 
The pragmatic and experimental features of the Saudi public administration commercial practices became apparent by the end of the 2000s. By that time, not all business centers in the country had been equally successful, especially in the healthcare sector. Many business centers that had been established in hospitals directly controlled by the Ministry of Health, in particular, had encountered various problems because of lack of facilities, personnel, skills and procedures to run services in a business-like manner (Walston et al. 2008). In 2008, the Ministry of Health required to close down business center subsidiaries that had delivered dissatisfying financial and healthcare performance. Since then, part of public healthcare organizations only did continue provide services through the business centers.

\section{CONCLUSIONS}

Existing theoretical accounts of the commercialization of public services build on evidence primarily gathered from regimes of representative democracies. Reform experiences in countries like China, Russia, and Saudi Arabia, however, challenge existing theoretical accounts because features of neo-patrimonial systems seem to partially neutralize factors that are commonly related to public services commercialization. In the Saudi Arabia case, the commercialization of healthcare and education took place even if factors like ideology change, political turnover, financial crisis and pressure from international organizations were not operant. Characteristics of neo-patrimonial systems - specifically linked to a rentier state condition - contributed to limit the impact of these factors in Saudi Arabia, at least with respect to the role that these factors play in the theoretical accounts that have been formulated out of evidence gathered in the context of representative democracies. In contrast, the analysis of the Saudi Arabia case suggests that combinations of social mechanisms can help explain the adoption of the commercialization policy and its diffusion from the healthcare to the educational sectors. 
The Saudi Arabia case study suggests that theories about the commercialization reforms of public services should be partially amended in order to account for changes in the provision of public services that take place also outside the context of representative democracies. An analytic generalization that arises from the Saudi Arabia case study is that the factors that have been commonly related to public services commercialization - ideology change, political turnover, financial crisis and pressure from international organizations - are not necessary conditions for the adoption of commercialization policy. Another analytic generalization is that mechanisms of attribution of opportunities and threat, combined with those of actor certification and availability heuristics, can help explain how local conditions can play a causal role in the adoption and diffusion of commercialization policy. These generalizations amend existing theoretical accounts of public service commercialization, also by strengthening the argument that commercialization may arise as a pragmatic and experimental way to reforming public services in a piecemeal approach rather than as a wholesale reconfiguration of the scope and forms of public service delivery.

The theoretical amendment that arises from this case study seems more a matter of gradation than radical contrast, however. Rather than framing representative democracies and neo-patrimonial systems as mutually exclusive scenarios, researchers should be also attentive to changing features of the context-in-motion. The same Saudi Arabia context, for example, is one where features of the neo-patrimonial system (and of the rentier state economy) may become less relevant over time. The drop of oil prices in 2008 and then in 2014-15 reminded that shocks can undermined the fiscal sustainability of the Saudi government. The launch of Vision 2030 marked an explicit acknowledgement that the transition to a post-oil economy will have various repercussions on public finances, privatization, and reforms of the job market. Already in 2017, the Saudi government was reported to seek a US\$10 billion loan from the IMF. The opening to foreign creditors could bring about important modifications to the Saudi political and institutional regime, whose effects might impact onto the system of delivery of public services too. 
This study contains some limitations that should be duly acknowledged. First, the analysis of the Saudi Arabia case results in the formulation of hypothetical causal claims that, admittedly, partially build on the interpretative work of the researchers. Second, the results of the analysis of the Saudi Arabia case take the form of 'limited generalizations' (Ragin 1987) which provide some tentative steps to repair existing propositions about public services reforms. The findings from the present case study cannot be plainly generalized in a statistical sense (Bengtsson and Hertting 2014; Elman et al. 2016; Flyvbjerg 2006; Thomas 2010), although they help enriching our understanding of public services reforms in non-Western country contexts. In addition, further research is needed to provide a more fine-grained account of the process dynamics and performance effects of the commercialization of healthcare and education in Saudi Arabia.

In addition, this study also indicates some ways to carry forward a research program that aims to enrich theoretical accounts of public sector reforms outside the context of representative democracies. Common (2008) already highlighted that public sector reforms in the Middle East are overlooked by researchers in comparative public administration, although they offer useful insights into administrative change because they defy standard assumptions about pressure for reform. Further comparative research could help identify conditions, rationales, and tendencies towards change in the provision of public services in neo-patrimonial systems and formulate more general context-independent theories of public sector reform. 
Table 1: List of major business centers in healthcare and education

\begin{tabular}{lc}
\multicolumn{1}{c}{ Business Center } & Sector \\
\hline King Saud University - King Abdullah Center for Consulting & Education \\
\hline $\begin{array}{l}\text { Dhahran Technology Valley of King Fahd University of Petroleum and } \\
\text { Minerals }\end{array}$ & Education \\
\hline King Abdulaziz University - Expertise House & Education \\
\hline Imam Muhammad Ibn Saud Islamic University-Prince Naif Institute for & Education \\
Research and Consulting Services & \\
\hline Institute of Public Administration (IPA)- Business Center & Education/Training \\
\hline Al-Majmaah University - King Salman Institute for Studies and & Education \\
Advisory Services & Health \\
\hline King Khalid University Hospital Business Center & Health \\
\hline King Abdulaziz University Hospital Business Center & Health \\
\hline The King Faisal Specialist Hospital and Research Centre Business & Health \\
\hline Center (evening private clinic) & \\
\hline Ministry of Health Hospitals (multiple Business Centers) & \\
\hline National Guard Health Affairs Business Center & \\
\hline
\end{tabular}


Table 2. Components of the explanatory argument

\begin{tabular}{ll}
\hline $\begin{array}{l}\text { Hypothesized causal } \\
\text { conditions }\end{array}$ & $\begin{array}{l}\text { Causal conditions confronted } \\
\text { with Saudi Arabia case evidence }\end{array}$ \\
\hline 1) Ideological change & $\begin{array}{l}\text { The political and institutional } \\
\text { regime resists dramatic } \\
\text { ideological change }\end{array}$ \\
$\begin{array}{l}\text { 2) Political turnover } \\
\text { The political and institutional } \\
\text { regime obstructs political } \\
\text { turnover while it ensures } \\
\text { continuity along dynastic lines }\end{array}$ \\
$\begin{array}{l}\text { 3) Pressure from financial } \\
\text { crisis }\end{array}$ & $\begin{array}{l}\text { Conditions of the oil rentier state } \\
\text { make the economy shielded from } \\
\text { pressures from financial crisis. }\end{array}$
\end{tabular}

Mediating social
mechanisms
Committed
interpretation

New or revised causal conditions

Actor certification

Public service reform

ideas can be adapted to

provide limited

autonomy for

commercial entities can be initiated by present rulers in power

\author{
Committed \\ interpretation
}

4) Pressure from international organizations

Conditions of the oil rentier state make the economy shielded from pressures from international organizations.

5) Anticipation of future financial crisis

6) Retention of skilled professionals

7) Influence of policy antecedents and policy brokers
Expectation of a post-oil economy calls for new ways of funding public service investments

Requirement to retain skilled professionals calls for new ways to improve salary conditions

No evidence of policy transfer from abroad but indication of cross-sectoral transfer from educational to healthcare
Actor certification

Attribution of opportunities and threats

Attribution of opportunities and threats

Actor certification Availability heuristics
No financial crisis exerts reform pressures if the economy is believed to be strongly rooted on oil rent

No international organization exerts reform pressures if the economy is self-reliant on oil rent

Public service reform can take place in anticipation of future financial crisis

Public service reform can take place to help retain skilled professionals

Reform features can be transferred across parts of the public sector 


\section{REFERENCES}

Al-Ahmadi, H. and Roland, M. (2005) 'Quality of primary health care in Saudi Arabia: A comprehensive review'. International Journal for Quality in Health Care, 17:4 pp331-346.

Al-Awaji, I. (1971) Bureaucracy and Society in Saudi Arabia. PhD Thesis. University of Virginia.

Al-Otaibi, A. (2010) An Assessment of the Role of Organisational Culture in Health Care Provision in Saudi Arabia. PhD Thesis. University of Manchester.

Al-Otaibi, M. Z. (2006) The Administrative Reforms in Saudi Arabia and Other Countries. Riyadh: Institute of Public Administration.

Al-Sheri, M. (2010) 'Saudi physicians only represent $15-20 \%$ of the population needs'. Al-Riyadh Newspaper, Available from: http://www.alriyadh.com/2008/04/3

Al-Tawail, A. (1995) Public Administration in the Kingdom of Saudi Arabia. Riyadh: Institute of Public Administration.

Ball, S. J. and Youdell, D. (2008) Hidden Privatisation in Public Education. Brussels: Education International.

Barabashev, A. and Straussman, J. D. (2007) 'Public Service Reform in Russia, 1991-2006'. Public Administration Review, 67:3 pp373-382.

Barakat, H. (1993) The Arab World: Society, Culture, and State. Berkeley, CA: University of California Press.

Barr, N. (1993) 'Alternative funding resources for higher education'. The Economic Journal, 103:418 pp718-728.

Barzelay, M. and Gallego, R. (2006) 'From "new institutionalism" to "institutional processualism": Advancing knowledge about public management policy change'. Governance, 19:4 pp531-557.

Barzelay, M. and Gallego, R. (2010) 'The comparative historical analysis of public management policy cycles in France, Italy, and Spain: Symposium conclusion'. Governance, 23:2 pp209223.

Bates, R. H., Greif, A., Levi, M., Rosenthal, J.-L. and Weingast, B. (1998) Analytic Narratives. Princeton, NJ: Princeton University Press.

Beeson, M. and Firth, A. (1998) 'Neoliberalism as a political rationality: Australian public policy since the 1980s'. Journal of Sociology, 34:3 pp215-231.

Bengtsson, B., and Hertting, N. (2014) 'Generalization by mechanism: Thin rationality and idealtype analysis in case study research'. Philosophy of the Social Sciences, 44:6 pp707-732.

Bertucci, G. (2004) Innovation in Governance and Public Administration: Regional Challenges and Responses. Doha: Doha Development Forum.

Bjerke, B. and Al-Meer, A.-M. (1993) 'Culture' s conseqences: Management in Saudi Arabia'. Leadership \& Organization Development, 14:2 pp30-35. 
Bloom, G. (2011) 'Building institutions for an effective health system: Lessons from China's experience with rural health reform'. Social Science \& Medicine, 72:8 pp1302-1309.

Bloom, G. and Xingyuan, G. (1997) 'Health sector reform: Lessons from China'. Social Science \& Medicine, 45:3 pp351-360.

Bratton, M. and van de Walle, N. (1997) DemocraticEexperiments in Africa: Regime Transitions in Comparative Perspective. Cambridge, MA: Cambridge University Press.

Brewer, G. A. and Walker, R. M. (2010) 'Explaining variation in perceptions of red tape: A professionalism-marketization model'. Public Administration, 88:2 pp418-438.

Brown, K., Ryan, N. and Parker, R. (2000) 'New modes of service delivery in the public sector commercialising government services'. International Journal of Public Sector Management, 13:3 pp206-221.

Carlin, T. M. (2005) 'Debating the impact of accrual accounting and reporting in the public sector'. Financial Accountability \& Management, 21:3 pp309-336.

Carlin, T. M. and Guthrie, J. (2003) 'Accrual output based budgeting systems in Australia: The rhetoric-reality gap'. Public Management Review, 5:2 pp145-162.

Chapman, R. A. (1966) 'Prismatic theory in public administration: a review of the theories of Fred W. Riggs'. Public Administration, 44:4 pp415-434.

Christensen, T. and Laegreid, P. (2001) 'New public management: The effects of contractualism and devolution on political control'. Public Management Review, 3:1 pp73-94.

Common, R. (2008) 'Administrative change in the Gulf: Modernization in Bahrain and Oman'. International Review of Administrative Sciences, 74:2 pp177-193.

Creese, A. L. (1991) 'User charges for health care: a review of recent experience'. Health Policy and Planning, 6:4 pp309-319.

Dahl, A. and Soss, J. (2014) 'Neoliberalism for the common good? Public value governance and the downsizing of democracy'. Public Administration Review, 74:4 pp496-504.

Dixon, J. and Kouzmin, A. (1994) 'The commercialization of the Australian public sector: competence, elitism or default in management education?' International Journal of Public Sector Management, 7:6 pp52-73.

Dixon, J., Kouzmin, A. and Korac-Kakabadse, N. (1996) 'The commercialization of the Australian public service and the accountability of government'. International Journal of Public Sector Management, 9:5/6 pp23-36.

Dolowitz, D. P. and Marsh, D. (1996) 'Who learns what from whom: a review of the policy transfer literature'. Political Studies, 44:2 pp343-357.

Dolowitz, D. P. and Marsh, D. (2000) 'Learning from abroad: The role of policy transfer in contemporary policy-making'. Governance, 13:1 pp5-23. 
Eisenstadt, S. N. (1973) Traditional Patrimonialism and Modern Neopatrimonialism. London: Sage.

Elman, C., Gerring, J., and Mahoney, J. (2016) 'Case study research: Putting the quant into the qual'. Sociological Methods and Research, 45:3 pp375-391.

Erdmann, G. and Engel, U. (2006) 'Neopatrimonialism revisited: beyond a catch-all concept'. GIGA Working Paper No 16. Available at SSRN: https://ssrn.com/abstract=909183

Evans, D. B. and Etienne, C. (2010) 'Health systems financing and the path to universal coverage'. Bulletin of the World Health, 88:6 pp402-403.

Evers, A. (2005) 'Mixed welfare systems and hybrid organizations: Changes in the governance and provision of social services'. International Journal of Public Administration, 28:9-10 pp737748.

Fauconnier, G. and Turner, M. (2008) The Way we Think: Conceptual Blending and the Mind's Hidden Complexities. New York: Basic Books.

Fitzgerald, L. and Ferlie, E. (2000) 'Professionals: back to the future?' Human Relations, 53:5 pp713-739.

Flyvbjerg, B. (2006) 'Five misunderstandings about case-study research' Qualitative Inquiry, 12:2 pp219-245.

Gambetta, D. (1998) 'Concatenations of Mechanisms' in P. Hedström and R. Swedberg (eds) Social Mechanisms: An Analytical Approach to Social Theory. Cambdrige, MA: Cambridge University Press, pp102-124.

George, A. L. and Bennett, A. (2005) Case Studies and Theory Development in the Social Sciences. Cambdridge, MA: MIT Press.

Ghallager, E. B. (2002) 'Modernization and health reform in Saudi Arabia' in A. C Twaddle (ed.) Health Care Reform around the World. London: Auburn House, pp191-197.

Gigerenzer, G. and Gaissmaier, W. (2011) 'Heuristic decision making'. Annual Review of Psychology, 62:1 pp451-482.

Goldfinch, S. and Wallis, J. (2010) 'Two myths of convergence in public management reform'. Public Administration, 88:4 pp1099-1115.

Goodrick, E. and Reay, T. (2011) 'Constellations of institutional logics: Changes in the professional work of pharmacists'. Work and Occupations, 38:3 pp372-416.

Gordeev, V. S., Pavlova, M. and Groot, W. (2011) 'Two decades of reforms. Appraisal of the financial reforms in the Russian public healthcare sector'. Health Policy, 102:2-3 pp270-277.

Greenaway, D. and Haynes, M. (2003) 'Funding higher education in the UK: The role of fees and loans'. The Economic Journal, 113:485 ppF150-F166.

Greve, C. (2006) 'Public management reform in Denmark'. Public Management Review, 8:1 pp161169. 
Gulrajani, N. and Moloney, K. (2012) 'Globalizing public administration: Today's eesearch and tomorrow's agenda'. Public Administration Review, 72:1 pp78-86.

Haque, M. S. (2001) 'The diminishing publicness of public service under the current mode of governance'. Public Administration Review, 61:1 pp65-82.

Harvey, D. (2007a) A Brief History of Neoliberalism. Oxford: Oxford University Press.

Harvey, D. (2007b) 'Neoliberalism as creative destruction'. The Annals of the American Academy of Political and Social Science, 610:1 pp21-44.

Hedström, P. (2005) Dissecting the Social: On the Principles of Analytical Dociology. Cambridge, MA: Cambridge University Press.

Hedström, P. and Swedberg, R. (1998) Social Mechanisms: An Analytical Approach to Social Theory. Cambridge, MA: Cambridge University Press.

Helmke, G. and Levitsky, S. (2004) 'Informal institutions and comparative politics: A research agenda'. Perspectives on Politics, 2:4 pp725-740.

Hercot, D., Meessen, B., Ridde, V. and Gilson, L. (2011) 'Removing user fees for health services in low-income countries: a multi-country review framework for assessing the process of policy change'. Health Policy and Planning, 26:suppl 2 ppii5-ii15.

Homedes, N. and Ugalde, A. (2005) 'Why neoliberal health reforms have failed in Latin America'. Health Policy, 71:1 pp83-96.

Hood, C. (1991) 'A Public Management for All Seasons?' Public Administration, 69:1 pp3-19.

Hood, C. (1995a) 'Contemporary public management: a new global paradigm?' Public Policy and Administration, 10:2 pp104-117.

Hood, C. (1995b) 'The "New Public Management" in the 1980s: Variations on a theme'. Accounting, Organizations and Society, 20:2-3 pp93-109.

Hood, C. (2000) 'Paradoxes of public-sector managerialism, old public management and public service bargains'. International Public Management Journal, 3:1 pp1-22.

Hood, C. and Dixon, R. (2015) A Government that Worked Better and Cost Less? Evaluating Three Decades of Reform and Change in UK Central Government. Oxford: Oxford University Press.

Idris, A. M. (2007) 'Cultural barriers to improved organizational performance in Saudi Arabia'. SAM Advanced Management Journal, 72:2 p36-52.

Jabbra, J. and Jabbra, N. (2005) 'Administrative Culture in the Middle East' in O. P. Dwivedi (ed.) Administrative Culture in a Global Context. Whitby, ON: de Sitter, pp135-153.

Jordan, B. (2006) 'Public services and the service economy: individualism and the choice agenda'. Journal of Social Policy, 35:1 pp143-162.

Joyce, P. (1999) Strategic Management for the Public Services. Buckingham: Open University 
Press.

Kamrava, M. and Mora, F. O. (1998) 'Civil society and democratisation in comparative perspective: Latin America and the Middle East'. Third World Quarterly, 19:5 pp893-915.

Laegreid, P., Roness, P. G. and Verhoest, K. (2011) 'Explaining the innovative culture and activities of state agencies'. Organization Studies, 32:10 pp1321-1347.

Lagarde, M. and Palmer, N. (2011) 'The impact of user fees on access to health services in low- and middle-income countries'. The Cochrane Database of Systematic Reviews, 4(CD009094).

Lebow, R. N. (2000) 'What's so different about a counterfactua;?' World Politics, 52:4 pp550-585.

Leung, J. (1990) 'The community-based welfare system in China'. Community Development Journal, 25:3 pp195-205.

Lindberg, S. I. (2003) 'It's out time to "chop": Do elections in Africa feed neo-patrimonialism rather than counter-act it?' Democratization, 10:2 pp121-140.

Lucas, R. E. (2004) 'Monarchical authoritarianism: survival and political liberalization in a middle eastern regime type'. International Journal of Middle East Studies, 36:1 pp103-119.

Lucio, M. M., Noon, M. and Jenkins, S. (1997) 'Constructing the market: Commercialization and privatization in the Royal Mail'. Public Administration, 75:2 pp267-282.

Marginson, S. and Considine, M. (2000) The Enterprise University: Power, Governance and Reinvention in Australia. Cambdridge: Cambridge University Press.

Mascarenhas, R. C. (1993) 'Building an enterprise culture in the public sector: Reform of the public sector in Australia, Britain, and New Zealand'. Public Administration Review, 53:4 pp319-328.

McAdam, D., Tarrow, S. G. and Tilly, C. (2001) Dynamics of Contention. Cambridge, MA: Cambridge University Press.

McGivern, G., Currie, G., Ferlie, E., Fitzgerald, L. and Waring, J. (2015) Hybrid managerprofessionals' identity work: The maintenance and hybridization of medical professionalism in managerial contexts'. Public Administration Review, 93:2 pp412-432.

McLaughlin, K., Osborne, S. P. and Ferlie, E. (2002) New Public Management: Current Trends and Future Prospects. London: Routledge.

Mellahi, K. (2006) 'Human resource management in Saudi Arabia' in P. S. Budhwar and K. Mellahi (eds) Managing Human Resources in the Middle-East. London: Routledge, pp1-19.

Miranda, R. and Lerner, A. (1995) 'Bureaucracy, organizational redundancy, and the privatization of public services'. Public Administration Review, 55:2 pp193-200.

Moloney, K. (2007) 'Comparative Bureaucracy: Today as Yesterday'. Public Administration Review, 67:6 pp1083-1086.

Montgometry, K. (2001) 'Physician executives: The evolution and impact of a hybrid profession'. Advances in Health Care Management, September pp215-241. 
Mossialos, E., Dixon, A., Figueras, J. and Kutzin, J. (2002) Funding Health Care: Options for Europe. Buckingham: Open University Press.

Neshkova, M. I. and Kostadinova, T. (2012) 'The effectiveness of administrative reform in new democracies'. Public Administration Review, 72:3 pp324-333.

O'Faircheallaigh, C., Wanna, J. and Weller, P. (1999) Public Sector Management in Australia: New Challenges, New Directions. South Melbourne: Macmillan.

Peters, B. G. and Savoie, D. J. (1994) 'Civil service reform: Misdiagnosing the patient'. Public Administration Review, 54:5 pp418-425.

Pollitt, C. (2013) Context in Public Policy and Management: The Missing Link? London: Edward Elgar.

Pollitt, C. and Bouckaert, G. (2004) Public Management Reform: A Comparative Analysis. Oxford: Oxford University Press.

Pollitt, C. and Talbot, C. (2003) Unbundled Government. Routledge Studies in Public Management. London: Routledge.

Powell, M., Greener, I., Szmigin, I., Doheny, S. and Mills, N. (2010) 'Broadening the focus of public service consumerism'. Public Management Review, 12:3 pp323-339.

Prinja, S., Aggarwal, A. K., Kumar, R. and Kanavos, P. (2012) 'User charges in health care: evidence of effect on service utilization \& equity from north India'. Indian Journal of Medical Research, 136:5 pp868-876.

Ragin, C. C. (1987) The Comparative Method. Berkeley, CA: University of California Press.

Reay, T. and Hinings, C. R. (2009) 'Managing the rivalry of competing institutional logics'. Organization Studies, 30:6 pp629-652.

Rechel, B. and McKee, M. (2009) 'Health reform in central and eastern Europe and the former Soviet Union'. The Lancet, 374:9696 pp1186-1195.

Riggs, F. (1964) Administration in Developing Countries: The Theory of Prismatic Society. Boston: Houghton Mifflin.

Ross, M. L. (1999) 'The political economy of the resource curse'. World Politics, 51:2 pp297-322.

Salancik, G. R. and Pfeffer, J. (1978) 'A social information processing approach to job attitudes and task design'. Administrative Science Quarterly, 23:2 pp224-253.

Schelling, T. C. (1998) 'Social mechanisms and social dynamics' in P. Hedström and R. Swedberg (eds) Social Mechanisms: An Analytical Approach to Social Theory. Cambdridge, MA: Cambridge University Press, pp32-44.

van Slyke, D. M. (2003) 'The mythology of privatization in contracting for social services'. Public Administration Review, 63:3 pp296-315. 
Spicer, B., Emanuel, D. and Powell, M. (1996) Transforming Government Enterprises. Sydney: Australian Centre for Independent Studies.

Steger, M. B. and Roy, R. K. (2010) Neoliberalism: A Very Short Introduction. Oxford: Oxford University Press.

Stone, D. (2004) 'Transfer agents and global networks in the "transnationalization" of policy'. Journal of European Public Policy, 11:3 pp545-566.

Tayeb, M. (2004) International Human Resource Management: A Multinational Company Perspective. Oxford: Oxford University Press.

Thomas, G. (2010) 'Doing case study: Abduction not induction, phronesis not theory'. Qualitative inquiry, 16:7 pp575-582.

Tummers, L. and Karsten, N. (2012) 'Reflecting on the Role of Literature in Qualitative Public Administration Research: Learning from Grounded Theory'. Administration \& Society, 44:1 pp64-86.

Walston, S., Al-Harbi, Y. and Al-Omar, B. (2008) 'The Changing Face of Healthcare in Saudi Arabia'. Annals of Saudi Medicine, 28:4 pp243-250.

Weber, M. (1968) On Charisma and Institution Building. Chicago: University of Chicago Press.

Welch, E. and Wong, W. (1998) 'Public administration in a global context: bridging the gaps of theory and practice between western and non-western nations'. Public Administration Review, 58:1 pp40-49.

Weyland, K. G. (2002) The Politics of Market Reform in Fragile Democracies: Argentina, Brazil, Peru, and Venezuela. Princeton, NJ: Princeton University Press.

Wise, C. R. (1990) 'Public service configurations and public organizations: Public organization design in the post-privatization era'. Public Administration Review, 50:2 pp141-155.

Wollmann, H. and Marcou, G. (2010) The Provision of Public Services in Europe: Between State, Local Government and Market. Cheltenham: Edward Elgar.

Wong, C. (2009) 'Rebuilding Government for the 21st Century: Can China Incrementally Reform the Public Sector?' The China Quarterly, 200 pp929-952.

Wright, D. S. and Sakurai, Y. (1987) 'Administrative reform in Japan: politics, policy, and public administration in a deliberative society'. Public Administration Review, 47:2 pp121-133.

Yin, R. K. (2003) Case Study Research: Design and Method. London: SAGE. 